\title{
Risk factors and prevalence of newborn hearing loss in a private health care system of Porto Velho, Northern Brazil
}

\author{
Fatores de risco e prevalência da deficiência auditiva neonatal em um sistema privado de saúde de \\ Porto Velho, Rondônia
}

Factores de riesgo y prevalencia de la deficiencia auditiva neonatal en un sistema privado de salud en Porto Velho, Rondônia (Brasil)

Juliana Santos de Oliveira', Liliane Barbosa Rodrigues², Fernanda Soares Aurélio ${ }^{2}$ Virgínia Braz da Silva ${ }^{4}$

\section{ABSTRACT}

Objective: To determine the prevalence of hearing loss and to analyze the results of newborn hearing screening and audiological diagnosis in private health care systems.

Methods: Cross-sectional and retrospective study in a database of newborn hearing screening performed by a private clinic in neonates born in private hospitals of Porto Velho, Rondônia, Northern Brazil. The screening results, the risk for hearing loss, the risk indicators for hearing loss and the diagnosis were descriptively analyzed. Newborns cared in rooming in with their mothers were compared to those admitted to the Intensive Care Unit regarding risk factors for hearing loss.

Results: Among 1,146 (100\%) enrolled newborns, 1,064 (92.8\%) passed and $82(7.2 \%)$ failed the hearing screening. Among all screened neonates, 1,063 (92.8\%) were cared in rooming and $83(7.2 \%)$ needed intensive care; $986(86.0 \%)$ were considered at low risk and $160(14.0 \%)$ at high risk for hearing problems. Of the 160 patients identified as having high risk for hearing loss, $83(37.7 \%)$ were admitted to an hospitalized in the Intensive Care Unit, 76 (34.5\%) used ototoxic drugs and $38(17.2 \%)$ had a family history of hearing loss in childhood. Hearing loss was diagnosed in two patients ( $0.2 \%$ of the screened sample).

Conclusions: The prevalence of hearing loss in newborns from private hospitals was two cases per 1,000 evaluated pa- tients. The use of ototoxic drugs, admission to Intensive Care Unit and family history of hearing loss were the most common risk factors for hearing loss in the studied population.

Key-words: risk factors; hearing loss/diagnosis; neonatal screening.

\section{RESUMO}

Objetivo: Determinar a prevalência da perda auditiva e caracterizar os resultados da triagem auditiva neonatal e do diagnóstico audiológico de recém-nascidos provenientes de unidades privadas de saúde.

Métodos: Estudo transversal e retrospectivo no banco de dados da triagem auditiva neonatal realizada pela Clínica de Avaliação e Reabilitação da Audição, em recém-nascidos provenientes de unidades privadas de saúde da cidade de Porto Velho, Rondônia. Realizou-se análise descritiva do resultado da triagem, do risco para deficiência auditiva, dos indicadores de risco para deficiência auditiva e do diagnóstico. O alojamento conjunto foi comparado com a Unidade de Terapia Intensiva Neonatal quanto à ocorrência de indicadores de risco para deficiência auditiva.

Resultados: Dos $1.146(100 \%)$ recém-nascidos cadastrados, $1.064(92,8 \%)$ passaram e $82(7,2 \%)$ falharam na triagem auditiva. Destes, $1.063(92,8 \%)$ eram provenientes

\footnotetext{
Instituição: Curso de Fonoaudiologia da Faculdade São Lucas (FSL), Porto Velho, RO, Brasil

${ }^{1}$ Graduada em Fonoaudiologia pela FSL, Porto Velho, RO, Brasil

Especializada em Motricidade Orofacial pela Universidade Potiguar (UnP); Docente do Curso de Fonoaudiologia da FSL, Porto Velho, RO, Brasil ${ }^{3}$ Mestre em Distúrbios da Comunicação Humana pela Universidade Federal de Santa Maria (UFSM); Docente do Curso Fonoaudiologia e Pós-graduação em Audiologia da FSL, Porto Velho, RO, Brasil

${ }^{4}$ Especialista em Audiologia pela Irmandade da Santa Casa de Misericórdia de São Paulo (ISCMSP); Docente do Curso de Fonoaudiologia e Pós-graduação em Audiologia da FSL, Porto Velho, RO, Brasil
}

\author{
Endereço para correspondência: \\ Virgínia Braz da Silva \\ Rua Alexandre Guimarães, 1.927 - Areal \\ CEP 76804-212 - Porto Velho/RO \\ E-mail: virginia@saolucas.edu.br \\ Conflito de interesse: nada a declarar
}

Recebido em: 8/9/2012

Aprovado em: 18/2/2013 
do alojamento conjunto e $83(7,2 \%)$, da Unidade de Terapia Intensiva Neonatal; $986(86,0 \%)$ foram considerados de baixo risco e 160 (14,0\%), de alto risco para problemas de audição. Dos 160 pacientes identificados como de alto risco para deficiência auditiva, $83(37,7 \%)$ permaneceram internados em Unidade de Terapia Intensiva, 76 (34,5\%) fizeram uso de ototóxicos e 38 (17,2\%) apresentavam história familiar de deficiência auditiva na infância. A perda auditiva foi diagnosticada em $0,2 \%(n=2)$ da amostra.

Conclusões: A prevalência de perda auditiva nos recém-nascidos em unidades privadas de saúde foi de dois casos para cada mil recém-nascidos avaliados. O uso de ototóxicos, a internação em Unidade de Terapia Intensiva Neonatal e a história familiar de deficiência auditiva foram os fatores de risco para deficiência auditiva na infância mais frequentes nessa população.

Palavras-chave: fatores de risco; perda auditival diagnóstico; triagem neonatal.

\section{RESUMEN}

Objetivo: Determinar la prevalencia de pérdida auditiva y caracterizar los resultados de los exámenes auditivos neonatales y del diagnóstico audiológico de recién nacidos provenientes de unidades privadas de salud.

Métodos: Estudio transversal y retrospectivo en la base de datos de los exámenes neonatales realizados por la Clínica de Evaluación y Rehabilitación de la Audición - Limiar, en recién nacidos provenientes de unidades privadas de salud de la ciudad de Porto Velho, Rondônia (Brasil). Se realizó el análisis descriptivo del resultado de los exámenes, del riesgo para deficiencia auditiva, de los indicadores de riesgo para deficiencia auditiva y del diagnóstico. El alojamiento conjunto fue comparado con la Unidad de Terapia Intensiva Neonatal respecto a la ocurrencia de indicadores de riesgo para deficiencia auditiva.

Resultados: De los 1.146 (100\%) recién nacidos catastrados, $1.064(92,84 \%)$ aprobaron y $82(7,16 \%)$ fallaron en los exámenes auditivos. De estos, $1.063(92,75 \%)$ eran provenientes del alojamiento conjunto y $83(7,25 \%)$, de la Unidad de Terapia Intensiva Neonatal; 986 (86\%) eran considerados de bajo riesgo y $160(14 \%)$ de alto riesgo para problemas de audición. De los 160 pacientes identificados como de alto riesgo para deficiencia auditiva, $83(37,7 \%)$ permanecieron internados en Unidad de Terapia Intensiva, $76(34,5 \%)$ utilizaron ototóxicos y $38(17,2 \%)$ presentaban historia familiar de deficiencia auditiva en la infancia. La pérdida auditiva fue diagnosticada en $0,2 \%(\mathrm{n}=2)$ de la muestra.
Conclusiones: La prevalencia de pérdida auditiva en los recién nacidos en unidades privadas de salud fue de dos casos para cada mil recién nacidos evaluados. El uso de ototóxicos, la internación en Unidad de Terapia Intensiva Neonatal y la historia familiar de deficiencia auditiva fueron los factores de riesgo para deficiencia auditiva en la infancia más frecuentes en esa población.

Palabras clave: factores de riesgo; pérdida auditiva/ diagnóstico; exámenes neonatales.

\section{Introduction}

The integrity of the auditory system is one of the prerequisites for the acquisition and the proper development of oral language, since it is through interaction with others that children acquire language, understand their universe, their peers, develop and organize thoughts and feelings, and gain knowledge ${ }^{(1)}$.

Hearing impairment is defined as a decreased ability to perceive sound, in which there is a deviation or change in structures or in their function, outside the limits of normality $^{(2)}$. It also represents a public health problem ${ }^{(3)}$ due to its impact on the citizen, and that is why hearing loss in neonates should be detected early, being the newborn hearing screening program, therefore, indispensable ${ }^{(4)}$.

In developed countries, hearing loss affects one in every thousand newborns $(\mathrm{NB})^{(5)}$. In Brazil, there are few population-based studies involving neonates; however, one study conducted in the municipality of São Paulo found a prevalence of $2.4 / 1,000^{(6)}$ and a study conducted in the municipality of Porto Velho, showed a prevalence of $2 / 1,000^{(7)} \mathrm{NBs}$.

Newborn hearing screening (NHS) comprises detecting hearing impairment in newborns, and it should be performed by electrophysiological measurements, such as brainstem auditory evoked potentials (BAEP) and/or otoacoustic emissions $(\mathrm{OAE})^{(2,8)}$. However, the diagnosis of childhood hearing loss should contemplate, besides the hearing screening procedures, the research of risk indicators for hearing loss (RIHL) and the follow-up of all infants who present such indicators ${ }^{(9)}$, as it will allow appropriate planning of the prevention of hearing loss.

The NHS is a reality in the public maternities in Porto Velho, Rondônia, but hospitals and private maternities in the municipality do not perform this service at hospital discharge, as recommended in the literature ${ }^{(2,8,9)}$. The implementation of universal NHS in all hospitals and maternities in the country is not only a necessity, due to the magnitude of the losses that hearing impairment brings to the individual, but also a 
legal requirement, since the law n. 12.303, from August 2, 2010, disposes about the obligation of conducting the evoked otoacoustic emissions (EOAE) test in children who are born in every hospital and maternity in the country ${ }^{(10)}$.

To be able to plan a program for the prevention and detection of hearing loss in a population, it is necessary that each hospital, health service, or region meets and monitors the occurrence of $\mathrm{RIHL}^{(9)}$ and the actual hearing loss. Therefore, the aim of this study was to characterize the results of newborn hearing screening, the audiological diagnosis, and the risk indicators from NBs coming from private health units who were assisted at the Clinic for the Assessment and Rehabilitation of Hearing - Limiar.

\section{Method}

This was a cross-sectional retrospective study, approved by the Research Ethics Committee of Faculdade São Lucas, under $\mathrm{n}$. 567/11. The study included data from infants from private health units in the municipality of Porto Velho, who were registered in the database of NHS on the date of collection; data from NBs who did not complete the process of screening and/or diagnosis were excluded.

The study was conducted in the Clinic for the Assessment and Rehabilitation of Hearing - Limiar, a reference unit in hearing loss, responsible for the NHS performed in two public maternities in the municipality of Porto Velho, besides meeting the demand of NBs from private hospitals and maternities. The municipality has six private hospitals; five are general hospitals with beds exclusively for obstetrics and for the neonate at high risk. The NBs are referred to perform NHS by pediatricians who work in the health units and/or in private clinics in the municipality.

The newborn hearing screening performed by this clinic follows the protocol recommended by the Universal Neonatal Hearing Screening Support Group (Grupo de apoio à triagem auditiva neonatal universal - GATANU) ${ }^{(9)}$. The NHS is performed by electrophysiological measures, with transient otoacoustic emissions (TOAE) in NBs at low risk and combined technique of TOAE and automatic brainstem evoked auditory potentials (A-BEAP) in NBs at high risk for hearing loss. The NBs with satisfactory results ("pass") in the NHS are considered normal, whereas those with unsatisfactory results ("fail") in the first test are subjected to a new test in 15 days, at most ("retest"). If there is persistent failure in the screening test, the NB is referred to audiological diagnostic procedures (otorhinolaryngology consultations, brainstem evoked auditory potentials (BEAP) exams, distortion product otoacoustic emissions (DPOAE), acoustic impedance audiometry, and behavioral observation) in the same clinic. The procedure is performed according to otorhinolaryngology medical criteria, and NBs with sensorineural hearing loss are often referred to prothetization, phonoaudiological therapy, and family counseling.

The NBs at high risk, even those who passed neonatal screening, are also monitored for up to 24 months regarding the hearing and language development due to the risk of late-onset hearing loss ${ }^{(2,8)}$. The criterion used to identify NBs at high risk for hearing loss is that recommended by the Joint Committee on Infant Hearing ${ }^{(2)}$, which considers a high risk infant the one who presents any of the following indicators: having been admitted to the Neonatal Intensive Care Unit (NICU) for more than 5 days, exposure to ototoxic medications associated or not to loop diuretics, assisted ventilation, hyperbilirubinemia that requires exchange transfusion, syndromes associated with hearing loss, family history of childhood hearing loss, craniofacial abnormalities, and in utero infections, such as cytomegalovirus, rubella, toxoplasmosis, herpes or syphilis. Besides these indicators, it should be considered that the municipality of Porto Velho is located in a region of high incidence of malaria. Pregnant women affected by this disease have high-risk pregnancies ${ }^{(11)}$, resulting, often, in miscarriage, premature birth and/ or underweight NBs. These women make use of antimalarial drugs, which are potentially ototoxic ${ }^{(12-14)}$, and, therefore, their NBs are considered of high risk for hearing loss.

Data collection was performed with the HITRACK 3.5 software, which was used for management of data on NHS and medical records of infants from the clinic. To collect data in this software, the name of the maternity or private hospital in the municipality was used as a filter to issue a report in which it was possible to identify: the number of infants registered in the database, the number of infants who passed or failed the NHS, the number of NBs who presented hearing risk indicators, the frequency of each risk indicator, and the number of NBs coming from rooming-in units or the NICU. A list of the NBs who failed the NHS and were referred for diagnosis was also issued, and the results of diagnostic evaluation were verified in their medical records. In cases of confirmed hearing loss, we observed the type and degree of hearing loss, the presence of RIHL in childhood, and the origin of the NB (rooming-in unit or NICU).

Data were analyzed regarding the frequency of the NHS result ("pass"/ "fail"), the risk for hearing loss, the RIHL, and the diagnosis result. The stay in a rooming-in unit was compared to the stay in the NICU regarding the occurrence of RIHL. For the statistical analysis, a test for equality of two 
proportions was used. The level of significance for statistical comparisons was established at $p \leq 0.05$.

\section{Results}

In the NHS database, on the date of data collection, there were 1,147 newborns registered from six private hospitals, who were screened in 2010. One newborn was excluded from the study, because he did not complete the process of diagnosis. Thus, the sample was composed of data from 1,146 infants.

Among these infants, $92.84 \%(n=1,064)$ passed the screening, presenting a satisfactory result, while $7.16 \%$

Table 1 - Frequency of occurrence of risk indicators in infants at high risk for childhood hearing loss from private health facilities in Porto Velho, state of Rondônia, Brazil

\begin{tabular}{lrr}
\hline & $\mathbf{n}$ & \multicolumn{1}{c}{$\%$} \\
\hline Perinatal asphyxia & 1 & 0.5 \\
Family history of HL & 38 & 17.2 \\
Syphilis & 3 & 1.5 \\
Malaria & 6 & 3.0 \\
Stay in the NICU & 83 & 37.7 \\
Use of ototoxic drugs & 76 & 34.5 \\
Craniofacial anomalies & 7 & 2.2 \\
Hyperbilirubinemia & 1 & 0.5 \\
Rubella & 1 & 0.5 \\
Varicella & 1 & 0.5 \\
Herpes & 1 & 0.5 \\
Toxoplasmosis & 2 & 1.0 \\
\hline
\end{tabular}

HL: hearing loss; NICU: Neonatal Intensive Care Unit $(\mathrm{n}=82)$ failed. Regarding the origin of the 1,146 patients, $92.75 \%(\mathrm{n}=1,063)$ were from rooming-in units and $7.25 \%$ $(\mathrm{n}=83)$, from the NICU. When analyzing the presence of risk for childhood hearing loss, $86 \%(\mathrm{n}=986)$ were at low risk and $14 \%(\mathrm{n}=160)$ were at high risk. The NB at high risk for childhood hearing loss presented from one to three risk factors. Table 1 , shows the frequency of these indicators in high risk NBs and a higher occurrence of the indicator "having been admitted to the NICU for more than 5 days", followed by "use of ototoxic medications" and "family history of childhood hearing loss".

When comparing the frequency of occurrence of RIHL in neonates at high risk for hearing loss according to the place of hospital stay (rooming-in unit or NICU), it was observed that the length of stay in the NICU and the use of ototoxic drugs were more significant in the newborns who were admitted to the NICU while family history of hearing loss, craniofacial anomalies, and maternal malaria were more frequent in infants from rooming-in units. It was also noted that syphilis infection in pregnancy tended to be more important in NBs who stayed in rooming-in units (Table 2).

Among 82 infants who failed the NHS, two (2.4\%) were identified as having hearing loss: one with conductive mild type and another with severe sensorineural hearing loss. Both $\mathrm{NBs}$ were from rooming-in units and did not present risk indicators for childhood hearing loss.

The prevalence of hearing loss in the population studied was of $0.2 \%$, that is, two cases per thousand NBs evaluated.

Table 2 - Comparison of the frequency of risk factors in infants at high risk for hearing impairment between rooming-in newborns and those admitted to the Neonatal Intensive Care Unit at private health units in Porto Velho, state of Rondônia, Brazil

\begin{tabular}{|c|c|c|c|c|c|}
\hline \multirow{2}{*}{ RIHL } & \multicolumn{2}{|c|}{ Rooming-in } & \multicolumn{2}{|c|}{ NICU } & \multirow{2}{*}{$p$-value* } \\
\hline & $\mathbf{n}$ & $\%$ & $\mathbf{n}$ & $\%$ & \\
\hline Perinatal asphyxia & 0 & 0 & 1 & 1.3 & 0.298 \\
\hline Family history of $\mathrm{HL}$ & 36 & 46.8 & 2 & 2.4 & $<0.001$ \\
\hline Syphilis & 3 & 3.9 & 0 & 0.0 & 0.069 \\
\hline Malaria & 6 & 7.8 & 0 & 0.0 & 0.010 \\
\hline Stay in the NICU & 0 & 0.0 & 83 & 100.0 & $<0.001$ \\
\hline Use of ototoxic drugs & 17 & 22.1 & 59 & 71.1 & $<0.001$ \\
\hline Craniofacial anomalies & 7 & 9.1 & 0 & 0.0 & 0.005 \\
\hline Hyperbilirubinemia & 0 & 0.0 & 1 & 1.2 & 0.334 \\
\hline Rubella & 1 & 1.3 & 0 & 0.0 & 0.298 \\
\hline Varicella & 1 & 1.3 & 0 & 0.0 & 0.298 \\
\hline Herpes & 1 & 1.3 & 0 & 0.0 & 0.298 \\
\hline Toxoplasmosis & 2 & 2.6 & 0 & 0.0 & 0.140 \\
\hline
\end{tabular}

*Statistical test - Equality of two proportions; \%: relative value; NICU: Neonatal Intensive Care Unit; RIHL: risk indicator for hearing loss; HL: hearing loss 


\section{Discussion}

Hearing loss is considered a public health problem because of its prevalence, but, mainly due to the multiple consequences that it may cause to human development, in intellectual, social, linguistic, cognitive, emotional, and cultural aspects ${ }^{(3)}$. In a study whose aim was to better understand the risk factors for hearing loss and to obtain information on the time elapsed between suspicion, diagnosis, and intervention in children and adolescents with hearing loss at the Educational Audiology Service of Pontifícia Universidade Católica de São Paulo (PUC-SP), authors found that, in $43 \%$ of patients, there was suspicion of hearing loss in the 1st year of life; in $25 \%$ the diagnosis was made immediately after suspicion; and only $11 \%$ started treatment immediately after diagnosis ${ }^{(15)}$. Therefore, practices for early identification and establishment of programs for monitoring children with risk indicators and/ or suspicions of hearing loss are imperative.

In the state of Rondônia, the NHS became mandatory after the law n. 1.394, from September 16, 2004, and today it is a reality in the public maternities of the capital before hospital discharge. In infants from private hospitals and maternities, it is performed through referral by pediatricians after hospital discharge. The protocol adopted follows the recommendations of entities linked to child hearing health ${ }^{(8,16)}$, which is the NHS performed by electrophysiological measures (EOAT and/or A-BEAP).

Data analyzed in this study refer to the hearing screening performed after hospital discharge in a population of NBs in private health units, referred by their pediatricians, usually in the 1st month of life. However, it is recommended that the NHS be performed before hospital discharge, in order to enable universal screening, avoiding absence in the scheduled returns ${ }^{(2,9)}$, besides providing the NHS team with access to the medical records of the mother and the newborns, which contain important information regarding pregnancy and the living conditions of infants at birth. In this study, there was one case of absence in a return of a NB that was already in the process of diagnosis, and no cases were identified in the screening stage.

On the other hand, the performance of NHS before hospital discharge can also have a negative influence on the failure rate, which is associated to the number of hours of life of the NB in the moment of the test, since they may present, before 24 hours of life, amniotic fluid in the middle ear or vernix in the external ear canal, hampering the capture of otoacoustic emissions ${ }^{(17)}$. Several authors observed that the failure rate in the NHS with OAE performed before hospital discharge could reach values of $20 \%$ or more ${ }^{(3,7,16,18,19)}$. In this investigation, only $7.16 \%$ of infants failed the NHS, and that may be explained by the fact that it was applied after hospital discharge, when the NB probably had no more traces of vernix or amniotic fluid in the middle ear. A study that performed NHS after hospital discharge found higher failure rates $(12.3 \%)$ than those obtained in this investigation ${ }^{(4)}$. The institution where this research was conducted performs NHS in the municipality for 9 years, and the collected data are related to a recent period; therefore, the team may be considered knowledgeable about the procedure. However, the values found are still higher than the number of referrals for diagnosis recommended by the Multiprofessional Committee on Hearing Health $(<4 \%)^{(8)}$.

The importance of the study of risk indicators for hearing loss in children, besides assisting the phonoaudiologist in establishing conducts, is related especially to the fact that many of these indicators can lead to late-onset hearing loss, and/or progression of hearing loss existing at birth ${ }^{(9)}$. In a study whose aim was to assess the frequency of risk indicators and their influence on the manifestation of hearing loss in neonates, the authors concluded that the coexistence of indicators increases the likelihood of sensorineural hearing loss in newborns ${ }^{(20)}$. In this investigation, $14 \%$ of the population presented one or more RIHL, a result that was also observed in other studies ${ }^{(4)}$. This finding reinforces the need for research of the RIHL, since some of these indicators, aside from increasing the likelihood of hearing $\operatorname{loss}^{(20)}$, are also responsible for the late-onset hearing loss, being necessary to monitor the hearing of the $\mathrm{NB}$ at risk ${ }^{(2,10)}$.

Hospitalization in the NICU has been related to childhood hearing loss ${ }^{(2,21-23)}$, as well as the use of ototoxic drugs ${ }^{(2,23)}$. Among the RIHL identified in this study, admission to the NICU, the use of ototoxic drugs, and family history of hearing loss were the most frequent. In a research conducted in the NHS database of a private hospital in Maceió, state of Alagoas, the risk indicators more recurrent were hyperbilirubinemia, admission to the NICU, the use of ototoxic drugs, and family history of childhood hearing loss ${ }^{(19)}$. The findings of the present study differ in relation to the occurrence of hyperbilirubinemia, which may be explained by the fact that the information regarding the occurrence of risk indicators was obtained by interview with the family, when they brought the NB for the exam, but the relatives did not always know details about the medical conditions of the child during the neonatal period. However, in the study conducted in Maceió, the NHS was performed inside the hospital, enabling the professional to research the risk indicators in the infant's medical records.

A similar study ${ }^{(7)}$, performed in public hospitals in Porto Velho, found two infants with hearing loss of unknown etiology 
and one whose etiology was likely hereditary. In the present research, family history of hearing loss prevailed in rooming-in unit; however, the cases identified as having hearing loss did not have RIHL and were from this sector. This fact reinforces the need to complement the NHS with genetic testing, as about $60 \%$ of cases of congenital hearing loss are associated with hereditary factors ${ }^{(24)}$, and the identification of the genetic nature of hearing loss will enable genetic counseling ${ }^{(25)}$.

It is interesting to note that malaria in pregnancy was also a risk indicator of hearing loss with significant occurrence in rooming-in NBs, when compared to those who were admitted to the NICU. Although malaria is associated to poor pregnancy outcomes $^{(11)}$, in the studied sample such cases were only identified in rooming-in newborns and they did not present hearing loss.

The occurrence of diseases, physiological imbalances, potentially ototoxic therapeutic measures ${ }^{(22)}$, in addition to the sound pressure level, which is excessive in hospital and neonatal environments ${ }^{(26,27)}$, raise the prevalence of hearing loss in infants admitted to the intensive care units ${ }^{(22)}$. Other authors ${ }^{(28,29)}$ have observed association of hearing loss with admission to the NICU. A survey with 71 NBs at high risk found $22(30.9 \%)$ patients with hearing loss, showing a high incidence in this population ${ }^{(22)}$. However, such patients were assessed only with evoked otoacoustic emissions, explaining the discrepancy with the results obtained in the present investigation. The use of objective tests in newborn hearing screening, such as transient OAE and BEAP, is recommended ${ }^{(2,8,9)}$ but their results cannot be considered in isolation, because one may underestimate or overestimate hearing loss.

In this study, despite the fact that hearing loss in infants who spent time in the NICU was not detected, the use of ototoxic medications was noteworthy in this sector, compared to rooming-in infants. Among ototoxic drugs, aminoglycosides are the most widely used due to their high antimicrobial efficacy and low $\cos ^{(30)}$, but they can lead to late-onset hearing loss ${ }^{(2)}$, so it is necessary to perform the audiological monitoring of the patient for prolonged periods.

Regarding studies aimed at determining the frequency of congenital hearing loss in healthy NBs, a prevalence of $4.9 \%$ of hearing loss was found in Turkey ${ }^{(31)}, 4.2 \%$ in Pisa (Italy $)^{(32)}$ and $0.08 \%$ in a pilot study conducted in Japan ${ }^{(33)}$. In the present study, the prevalence of congenital hearing defects in NBs assessed was of $0.2 \%$, a finding that was lower than the results in Turkey and Italy and higher than those in Japan. Similar results were found in NHS programs in Brazil, such as in the studies performed in public hospitals in Belo Horizonte ${ }^{(34)}$ and Porto Velho ${ }^{(7)}$.

The importance of the universal NHS is due to the fact that $50 \%$ of babies with hearing loss have no risk factors for this impairment. Therefore, if the NHS is performed only in the NBs with risk factors, $50 \%$ of them may have a delayed diagnosis and intervention $^{(1)}$. It was observed in this study that both NBs who presented hearing loss did not have risk indicators for deafness.

In this study, it was not possible to identify whether all NBs from private health units in the study period performed the NHS, once the collection was limited to the database and the medical records of the NBs referred for diagnosis. However, the importance of using the NHS database became clear, once it allowed quick access to results, as it was also clear that the NHS performed after hospital discharge may limit the identification of the RIHL, since it is not possible to investigate them in the infants' medical records.

It can be concluded that the NBs from private health units in Porto Velho presented a prevalence of congenital hearing loss similar to that found in other national studies. The use of ototoxic drugs, hospitalization in the NICU, and family history of hearing loss were the most frequent risk factors for childhood hearing loss in this population, being family history the most frequent risk indicator among rooming-in infants, and the use of ototoxic drugs the most frequent risk indicator among those NBs admitted to the NICU.

\section{Acknowledgements}

We are thankful to the Clinic for the Assessment and Rehabilitation of Hearing (Clínica de Avaliação e Reabilitação da Audição) - Limiar, as well as to the team responsible for the newborn hearing screening, for the opportunity to conduct this study.

\section{References}

1. Hilú MR, Zeigelboim BS. The knowledge and valorization of neontal auditory screening and the early intervention of hearing loss. Rev CEFAC 2007; 9:563-70.

2. American Academy of Pediatrics, Joint Committee on Infant Hearing. Year 2007 position statement: principles and guidelines for early hearing detection and intervention programs. Pediatrics 2007;120:898-921.

3. Mattos WM, Cardoso LF, Bissani CB, Pinheiro MM, Viveiros CM, Carreirão Filho WC. Newborn hearing screening program implantation analysis at a University Hospital. Braz J Otorhinolaryngol 2009;75:237-44.

4. Lima MC, Rossi TR, Françozo MF, Marba ST, Lima GM, Santos MF. Detection of hearing loss in neonates of a public hospital. Rev Soc Bras Fonoaudiol 2010;15:1-6. 
5. Morzaria S, Westerberg BD, Kozak FK. Systematic review of the etiology of bilateral sensorineural hearing loss in children. Int $\mathrm{J}$ Pediatr Otorhinolyngol 2004;68:1193-8.

6. Chapchap MJ, Segre CM. Universal newborn hearing screening and transient evoked otoacoustic emission: new concepts in Brazil. Scand Audiol Suppl 2001; (Suppl 53):33-6.

7. Botelho MS, Silva VB, Arruda LS, Kuniyoshi IC, Oliveira LL, Oliveira AS. Newborn hearing screening in the limiar clinic in Porto Velho - Rondônia. Braz J Otorhinolaryngol 2010;76:605-10.

8. Lewis DR, Marone SA, Mendes BC, Cruz OL, Nóbrega M. Multiprofessional committee on auditory health: COMUSA. Braz J Otorhinolaryngol 2010; 76:121-8.

9. Gatanu [homepage on the Internet]. Grupo de Apoio à Triagem Auditiva Neonatal Universal [cited 2011 Oct 12]. Available from: http://www.gatanu.org

10. Brasil - Diário Oficial da União - República Federativa do Brasil [homepage on the Internet]. Lei $n^{\circ} 12.303$, de 2 de agosto de 2010. Dispõe sobre a obrigatoriedade de realização do exame denominado Emissões Otoacústicas Evocadas [cited 2013 Jun 04]. Available from: http://www.sbfa.org.br/boletins/ leiaotoacustica_20100803.pdf

11. Brasil - Ministério da Saúde. Secretaria de atenção à saúde - departamento de ações programáticas estratégicas. Gestação de alto risco: manual técnico. Brasília: Ministério da Saúde, 2010.

12. Oliveira JA, Cicilini GA, Souza ML, Andrade MH. Efeitos do quinino isolado e associado a antibióticos labirintotóxicos na estrutura e função labiríntica. Rev Bras Otorrinolaringol 1982;48:15-30.

13. Branco Neves MV. Estudio de los efectos ototóxicos en 725 pacientes tratados con antimaláricos en el hospital central de Maputo (Mozambique) [tese de doutorado]. Barcelona: UAB; 2004.

14. McCall MB, Beynon AJ, Mylanus EA, van der Ven AJ, Sauerwein RW. No hearing loss associated with the use of artemether-lumefantrine to treat experimental human malaria. Trans R Soc Trop Med Hyg 2006;100:1098-104.

15. Pupo AC, Baliero CR, Figueiredo RSL. Estudo retrospectivo de crianças e jovens com deficiência auditiva: caracterização das etiologias e quadro audiológico. Rev CEFAC 2008;10:84-91.

16. Melo AD, Duarte JL, Alvarenga KF, Agostinho-Pesse RS, Bevilacqua MC, Martinez MA. Influência do tempo de vida na pesquisa das emissões otoacústicas evocadas transientes em recém-nascidos. Disturb Comun 2007;19:357-64.

17. Simonek MC, Azevedo MF. False-positive results in newborn universal hearing screening: possible causes. Rev CEFAC 2011;13:292-8.

18. Berni PS, Almeida EO, Amado BC, Almeida Filho N. Universal neonatal screening: index of retest effectiveness among newborns of a public hospital in Campinas - Brazil. Rev CEFAC 2010;12:122-7.
19. Dantas MB, Anjos CA, Camboim ED, Pimentel Mde C. Results of a neonatal hearing screening program in Maceió. Braz J Otorhinolaryngol 2009;75:58-63.

20. Bielecki I, Horbulewicz A, Wolan T. Risk factors associated with hearing loss in infants: an analysis of 5282 referred neonates. Int J Pediatr Otorhinolaryngol 2011;75:925-30.

21. Uchôa NT, Procianoy RS, Lavinsky L, Sleifer P. Prevalence of hearing loss in very low birth weight neonates. J Pediatr (Rio J) 2003;79:123-8.

22. Sassada MM, Ceccon ME, Navarro JM, Vaz FA. Hearing loss in newborn admitted in Intensive Care Unit. Pediatria (Sao Paulo) 2005;27:163-71.

23. Câmara MF, Azevedo MF, Lima JW, Sartorato EL. Effects of ototoxic drugs in the hearing of high risk newborns. Rev Soc Bras Fonoaudiol 2010;15:376-82.

24. Piatto VB, Nascimento EC, Alexandrino F, Oliveira CA, Lopes AC, Sartorato EL et al. Molecular genetics of non-syndromic deafness. Braz J Otorhinolaryngol 2005; 71:216-23

25. Schmidt PM, Tochetto TM. Genetic investigation of hereditary deafness: connexin 26 gene mutation. Rev Soc Bras Fonoaudiol 2009;14:142-7.

26. Aurélio FS, Tochetto TM. Noise in a neonatal Intensive Care Unit: measurement and perception of professionals and parents. Rev Paul Pediatr 2010;28:162-9.

27. Kuniyoshi IC, Aguiar JS, Siva VB, Araújo VC, Chagas TA, Souza EC et al. O nível de ruído em uma unidade de terapia intensiva neonatal em Porto velho - Rondônia. Abstracts of the $17^{\circ}$ Congresso Brasileiro de Fonoaudiologia and $1^{\circ}$ Congresso Ibero-Americano de Fonoaudiologia; 2009 Oct 21-24; Salvador, Brasil. p. 2472.

28. Lima GM, Marba ST, Santos MF. Hearing screening in a neonatal intensive care unit. J Pediatr (Rio J) 2006;82:110-4.

29. Botelho FA, Bouzada MC, Resende LM, Silva CF, Oliveira EA. Prevalence of hearing impairment in children at risk. Braz J Otorhinolaryngol 2010;76:739-44.

30. Aquino TJ, Oliveira JA, Rossato M. Ototoxicity and otoprotection in the inner ear of guinea pigs using gentamicin and amikacin: ultrastructural and functional aspects. Braz J Otorhinolaryngol 2008;74:843-52.

31. Atas $\mathrm{B}$, Altunhan $\mathrm{H}$, Eryilmaz MA, Atas $\mathrm{E}$. Frequency of congenital hearing loss in 43,503 healthy newborn infants in Konya, Turkey. J Pak Med Assoc 2011;61:727-8.

32. Ghirri P, Liumbruno A, Lunardi S, Forli F, Boldrini A, Baggiani A et al. Universal neonatal audiological screening: experience of the University Hospital of Pisa. Ital J Pediatr [serial on the Internet]. 2011;37 [cited 2011 Dec 03]. Available from: http://www.ijponline.net/content/pdf/1824-7288-37-16.pdf

33. Fukushima K, Mimaki N, Fukuda S, Nishizaki K. Pilot study of universal newborn hearing screening in Japan: district-based screening program in Okayama. Ann Otol Rhinol Laryngol 2008;117:166-71.

34. Tiensoli LO, Goulart LM, Resende LM, Colosimo EA. Hearing screening in a public hospital in Belo Horizonte, Minas Gerais State, Brazil: hearing impairment and risk factors in neonates and infants. Cad Saude Publica 2007:23:1431-41. 